\title{
PRODUCTIVE REGIONAL CONCENTRATION IN THE STATE OF PARANÁ: A CASE STUDY OF NON-TIMBER FOREST PRODUCTS
}

\author{
Keila Correa Bittencourt ${ }^{*}$, Thiago Rodrigues de Paula ${ }^{2}$, Anadalvo Juazeiro dos Santos ${ }^{3}$, Roberto Tuyoshi \\ Hosokawa ${ }^{4}$,Vítor Afonso Hoeflich ${ }^{5}$ \\ 1* Federal University of Paraná, Postgraduate Program in Forest Engineering, Curitiba, Paraná, Brazil - keila_cbittencourt@ yahoo.com.br
${ }^{2}$ Federal University of Paraná, Postgraduate Program in Forest Engineering, Curitiba, Paraná, Brazil - uf_floresta@ @otmail.com
${ }^{3}$ Federal University of Paraná, Rural Economy and Extension Department, Curitiba, Paraná, Brazil - ajsantos.ufpr@ gmail.com
${ }^{4}$ Federal University of Paraná, Rural Economy and Extension Department,Curitiba, Paraná, Brazil - rth@ @onda.com.br
${ }^{5}$ Federal University of Paraná, Rural Economy and Extension Department, Curitiba, Paraná, Brazil - vitor.ufpr@gmail.com
}

Received for publication: 21/09/2017 - Accepted for publication: 29/01/2019

\begin{abstract}
Resumo
Concentração regional da produção no estado do paraná: estudo de caso dos produtos florestais não madeireiros. Os produtos florestais não-madeireiros (PFNMs) possuem significativo potencial produtivo no Estado do Paraná. Os cinco PFNMs mais representativos do estado são: erva mate, palmito (pupunha, juçara e real), pinhão, resina e látex. O estudo possui três objetivos considerando os PFNM's: (1) caracterizar as mesorregiões do Paraná sobre sua participação na produção; (2) identificar o potencial produtivo em cada uma das mesorregiões e; (3) demonstrar que o Quociente Locacional (QL) pode ser uma ferramenta na formulação de políticas públicas. Para tanto, utilizou-se a QL como instrumento de análise e diagnóstico, que demonstra o grau de concentração da produção em cada mesorregião. Assim, os formuladores de política têm uma base estatística para basear as suas decisões, no entanto, é necessária uma análise aprofundada pelas instituições competentes. Os resultados mostraram que há uma concentração de produção na região oeste e sudeste para a erva-mate, na região metropolitana de Curitiba, para a produção de palmito e todas as mesorregiões têm uma produção significativa de pinhão. A mesorregião metropolitana de Curitiba participa com a maior parte da produção de resina e mesorregião Noroeste, com a maior produção de látex. Conclui-se que uma análise regional utilizando o QL é uma ferramenta valiosa para caracterizar as mesorregiões e identificar o potencial produtivo dos cinco PFNMs mais importantes no estado. Assim, para incentivar o desenvolvimento regional, as partes interessadas podem incorporar essa análise em suas políticas, para permitir que a sociedade se beneficie.

Palavras-chave: Mesorregião, Desenvolvimento rural, Planejamento.
\end{abstract}

\begin{abstract}
Non-timber forest products (NTFPs) have a significant productive potential in the State of Paraná. The five most important NTFPs of Paraná are yerba mate, palm heart (pupunha, juçara, and real), pinhão, resin, and latex. The study has three objectives considering NTFP's: (1) characterize the mesoregions of Paraná based on their participation in the production ;(2) identify the productive potential in each mesoregion and; (3) to demonstrate that the Location Quotient (LQ) can be a tool in the formulation of public policies. To do so, LQ was used as an instrument of analysis and diagnosis to show the degree of concentration of production of the NTFPs in each mesoregion. The study showed that the production of yerba mate is concentrated in the middle, west, and southeast regions. The production of palm heart is concentrated in the Curitiba metropolitan mesoregion, and all the mesoregions produce a significant amount of pinhão. The Curitiba metropolitan mesoregion produces the highest amount of resin and the northwest mesoregion produces the highest amount of latex. In conclusion, it was proved that a regional analysis using LQ is a valuable tool for characterizing the Paraná mesoregions based on their participation in the production of the five most important NTFPs. In addition, it was proved that LQ is a valuable tool for identifying the productive potential of the mesoregions of the five most important NTFPs. Thus, to encourage regional development, stakeholders may incorporate this analysis in their policies, to enable the society to benefit.

Keywords: mesoregion, rural development, planning
\end{abstract}

\section{INTRODUCTION}

The amount and variety of non-timber forest products (NTFPs) and their importance for forest communities explain the myriad of settings applied to the subject. NTFPs are products from forests for human and industrial consumption, obtained from either native or planted forests, agroforestry, and even isolated trees, other than the wood itself. They are used for food, fuel, resins, medicines, gums, and fiber active compounds, as well as for environmental services provided by these environments (FAO, 2016; SANTOS et al., 2016). 
Products obtained for human consumption (food and drink like Brazil nuts, fruits and palm hearts, fungi (mushroom) and matte), resins, latex and essential oils (pine resin, natural rubber and essence of Eucalyptus), medicinal plants, fibers and construction materials (palm and bamboo fibers), as well as dyes and tannins are the most important NTFPs in South America. The Amazon region, the main regional exponent in the production of NTFPs, stands out in the production of Brazil nuts. And palm hearts contribute significantly to the revenue and crop of this region. In addition to Bolivia being a major producer (FAO, 2016).

The main NTFPs of Brazil are edible $(69 \%)$ like Brazil nuts, palm hearts, and yerba mate, followed by oleaginous (12\%), waxes (7\%), and fibers (4\%). In 2014, the total production of major NTFPs from natural forests was worth R $\$ 1,388$ million, with a growth trend compared to previous years. Production of NTFPs from planted forests, such as the black wattle (shells), eucalyptus (sheet), and pinus (resin) fell from 203,000 tons in 2013 to 166,000 tons in 2014. However, there was an increase in revenue from R\$ 143 million in 2013 to R\$ 216 million in 2014, meaning a greater appreciation in the value of the product represented by a higher price, (IBGE, 2014).

In the State of Paraná, the Gross Value of Production (GVP) of forest products was R 3.96 billion in 2013 , of which $88 \%$ is accounted for by logs of various assortments and $12 \%$ by NTFPs. The following are the main NTFPs originating from the State of Paraná: yerba mate, pinhão, palm hearts, latex, and resin (SEAB, 2015).

The purpose of this study is to analyze the production levels of NTFPs as well as their permanence and/or change over time in order to (1) characterize the mesoregions of Paraná based on their participation in the production of NFTPs in this state, (2) identify the productive potential of NTFPs in each mesoregion of the State of Paraná, and (3) demonstrate that the Location Quotient (LQ) can be a tool in the formulation of public policies to promote better organization of these productive chains. There is no study on non-timber forest products using the LQ as a method of analysis. Thus, the study contains references regarding the use of LQ in other areas.

\section{MATERIALS AND METHODS}

Mesoregions are subdivisions within a state that bring together several municipalities with close economic and social similarities, not constituting a political or administrative unit, for statistical purposes only. Data from surveys regionalized from mesoregions support regional planning and contribute to a better use of the productive potential of each of the municipalities (IBGE, 2014). The distribution of the mesoregions of the State of Paraná is shown below:

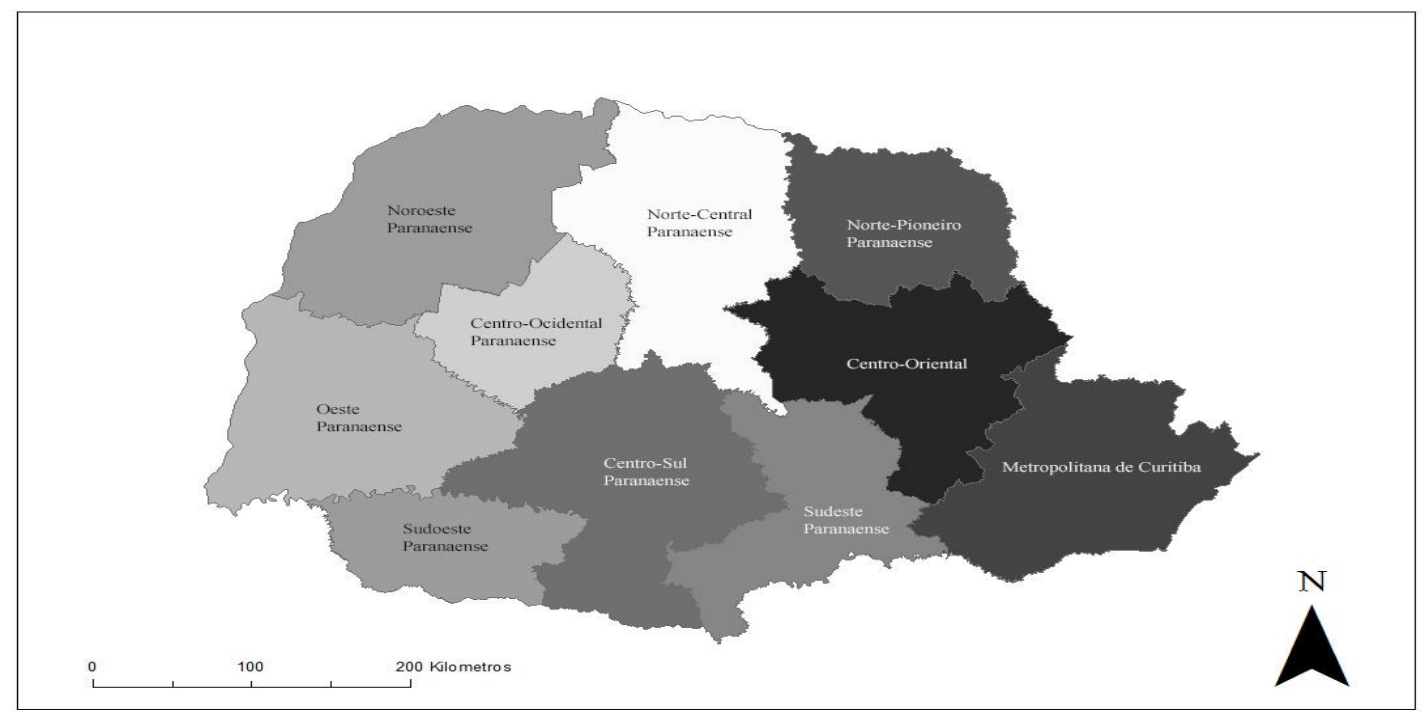

Source: Instituto de Pesquisa Econômica Aplicada (IPEA).Fonte:Instituto de Pesquisa Econômica Aplicada (IPEA).

Figure 1. Mesoregions of Paraná.

Figura 1. Mesorregiões do Paraná.

Regional and spatial analysis are characterized by using the relative weight of the studied regions, nullifying the effect size (physical) alone, not considering the physical extension, but the result that it is derived. According to Lima et al. (2006) and Marion Filho et al. (2015), several quantitative methods are used to analyze the expertise, geographic location, or association of a region. These methods include the following: (1) Location Quotient (LQ), (2) Location Coefficient (LC), (3) Coefficient of Specialization (CS), (4) Geographical Association 
Coefficient (GAC), (5) Restructuring Coefficient (Rc), and (6) Coefficient Redistribution (CRED). The analysis considers the concentration or dispersion of the variables analyzed for a particular region.

This study used Location Quotient (LQ) as an analytical tool of the productive concentration in Paraná, in the period between 2010 and 2014, for the following NFTPS: yerba mate (leaf), palm heart (juçara, pupunha, and real), pinhão, resin (pinus), and latex. The selected products are the most important in terms of production and the raw value of the production, besides having historical series production and being available. According to SEAB (2017), from 2017-2016, the forestry sector increased its participation in the GVP of Paraná by 3\%. The data were obtained via email and telephone from the SEAB since the data used have not been published on the website of the SEAB.

According to Lima et al. (2006), the LQ was adopted to compare the percentage share of a particular variable of a region in relation to the total percentage share with the state. can be seen from specific sectors, production, or the value of production, since depending on the type of analysis, a region may have more or less involvement. In other words, production is an amount of indicator while the value of output. The LQ shows how much was added to the monetary value of that product; therefore, increased participation in production does not mean a higher production value.

The regional economy literature considers three intervals analyzes of the LQ. First, LQ> 1 indicating a significant location, i.e., the region has importance in the productivity/value of the variable production analysis, and this region is represented by a municipality or several municipalities of a mesoregion. The higher the value the LQ, the greater the production concentration of the product in the mesoregion in question is. Secondly, $\leq 0.5 \leq 0.99$ LQ means average location because several municipalities produce the variable in the analysis. Finally, LQ $<0.49$ means the amount produced is low considering a municipality and / or the municipalities of the mesoregion (LIMA et al., 2006). Formula proposed by the literature:

$$
\mathrm{LQ}_{\mathrm{ij}}=\frac{\frac{E_{\mathrm{ij}}}{\sum E_{\mathrm{ij}}}}{\frac{\sum E_{\mathrm{ij}}}{\sum \sum E_{\mathrm{ij}}}}
$$

On what: LQ $>1 \rightarrow$ significant Location; $0.5 \leq \mathrm{LQ} \leq 0.99$ is average Location and LQ $<0.49$ is Poor Location.

Used equations and meaning of the variables:

Eij: Q produced quantity or product production value of mesoregion $\mathbf{i} \mathbf{j}$

$\Sigma_{\mathrm{j}}$ Eij: Quantity produced or product output value $\mathbf{i}$ of all the mesoregions

$\Sigma_{\mathrm{i}}$ Eij: Quantity produced or production value of all products of the middle mesoregion $\mathbf{j}$

$\Sigma_{\mathrm{i}} \Sigma_{\mathrm{j}}$ Eij: Quantity produced or production value of all products and all the mesoregions

The equations mean the following, for example: Eij means the amount of yerba mate produced in the central region-Western; $\Sigma_{\mathrm{j}}$ Eij means the amount of yerba mate produced in all of the 10 mesoregions; $\Sigma_{\mathrm{i}}$ Eij means the amount of yerba mate, palm heart, pinhão, resin, and latex produced from the central regionWestern; $\Sigma_{\mathrm{i}} \Sigma_{\mathrm{j}}$ Eij means the amount of yerba mate, heart palm, pinhão resin, and latex produced by the 10 mesoregions.

Thus, the LQ for all the analyzed variables of the producing mesoregion for 2010 and 2014 was calculated. In this paper, $120 \mathrm{LQs}$ featuring the five products of the producing mesoregions, $60 \mathrm{LQs}$ considering production, and $60 \mathrm{LQs}$ considering the value of production were calculated. The LQ enables the proposed objectives to be reached, since as a statistical diagnostic instrument, it allows for the measurement of how much each product participates in the production or production value of each region in percentage terms. 


\section{RESULTS}

The analysis time interval (2010-2014) enables comparisons given by alternations in the results, which can infer changes in the region in the production of NTFPs in bureaucratic issues that prevent its production, among other environmental determinants that may affect its cycle.

\section{LQ for physical production} period.

Table 1 shows the LQ for the production of the five most important NTFPs in Parana during the reporting

Table 1. Location Quotient (Paraná) - Production quantity (2010 and 2014)

Tabela 1. Quociente Locacional (Paraná) -Quantidade Produzida (2010 e 2014)

\begin{tabular}{|c|c|c|c|c|c|c|c|c|c|c|}
\hline Product & Yerb: & mate & Palm & Heart & & Ião & & & $\mathbf{L a}$ & \\
\hline Mesoregion & $\begin{array}{l}\text { Year } \\
2010\end{array}$ & $\begin{array}{l}\text { Year } \\
2014\end{array}$ & $\begin{array}{l}\text { Year } \\
2010\end{array}$ & $\begin{array}{l}\text { Year } \\
2014\end{array}$ & $\begin{array}{l}\text { Year } \\
2010\end{array}$ & $\begin{array}{l}\text { Year } \\
2014\end{array}$ & $\begin{array}{l}\text { Year } \\
2010\end{array}$ & $\begin{array}{l}\text { Year } \\
2014\end{array}$ & $\begin{array}{l}\text { Year } \\
2010\end{array}$ & $\begin{array}{l}\text { Year } \\
2014\end{array}$ \\
\hline Central West & 0.98 & 0.88 & 4.65 & 12.43 & 1.00 & 1.27 & - & - & - & - \\
\hline Central and Eastern & 0.97 & 1.01 & - & - & 0.94 & 0.98 & 4.86 & - & - & - \\
\hline South Center & 0.98 & 1.03 & - & - & 0.97 & 0.98 & 1.89 & 2.08 & - & - \\
\hline Curitiba metropolitan & 0.43 & 0.43 & 28.33 & 36.46 & 0.91 & 1.95 & 16.66 & 18.55 & - & - \\
\hline Northwest & - & - & 9.57 & 17.05 & 0.32 & 0.76 & - & - & 189.7 & 252.6 \\
\hline North pioneer & - & - & 81.52 & 84.65 & 1.19 & 3.14 & - & - & - & - \\
\hline North Central & 0.11 & 0.05 & 19.29 & 16.58 & 0.42 & 0.73 & - & - & 135.8 & 237 \\
\hline West & 1.03 & 1.02 & 0.47 & 0.37 & 0.99 & 0.97 & - & - & - & - \\
\hline Southeast & 0.20 & 1.03 & - & - & 1.02 & 1.25 & - & 0.08 & - & - \\
\hline Southwest & 1.03 & 0.97 & - & - & 0.98 & 0.91 & - & 8.57 & - & 0.43 \\
\hline
\end{tabular}

Source: Authors, 2016.

Fonte: Autores, 2016

\section{LQ for Production Value}

Table 2 shows the LQ for the production value of the five most important NTFPs in Paraná during the reporting period

Table 2. Location Quotient (Paraná) - Production value (2010 and 2014)

Tabela 2 Quociente Locacional (Paraná) - Valor de Produção (2010 and 2014)

\begin{tabular}{|c|c|c|c|c|c|c|c|c|c|c|}
\hline \multirow{2}{*}{$\begin{array}{l}\text { Product } \\
\text { Mesoregion }\end{array}$} & \multicolumn{2}{|c|}{ Yerba-mate } & \multicolumn{2}{|c|}{ Palm heart } & \multicolumn{2}{|c|}{ Pinhão } & \multicolumn{2}{|c|}{ Resin } & \multicolumn{2}{|c|}{ Latex } \\
\hline & $\begin{array}{l}\text { Year } \\
2010\end{array}$ & $\begin{array}{l}\text { Year } \\
2014\end{array}$ & $\begin{array}{l}\text { Year } \\
2010\end{array}$ & $\begin{array}{l}\text { Year } \\
2014\end{array}$ & $\begin{array}{l}\text { Year } \\
2010\end{array}$ & $\begin{array}{l}\text { Year } \\
2014 \\
\end{array}$ & $\begin{array}{l}\text { Year } \\
2010\end{array}$ & $\begin{array}{l}\text { Year } \\
2014 \\
\end{array}$ & $\begin{array}{l}\text { Year } \\
2010\end{array}$ & $\begin{array}{l}\text { Year } \\
2014\end{array}$ \\
\hline Central West & 0.78 & 0.69 & 3.5 & 9.77 & 1.03 & 1 & - & - & - & - \\
\hline Central and Eastern & 0.96 & 1.03 & - & - & 0.87 & 0.99 & 4.83 & - & - & - \\
\hline South Center & 1.04 & 1.08 & - & - & 0.96 & 3.7 & 1.99 & 0.6 & - & - \\
\hline Curitiba metropolitan & 0.11 & 0.20 & 6.98 & 17.03 & 0.88 & 0.91 & 5.19 & 2.52 & - & - \\
\hline Northwest & - & - & 1.91 & 7.79 & 0.23 & 0.35 & - & - & 4.36 & 33.56 \\
\hline North pioneer & - & - & 9.71 & 26.87 & 1.04 & 1 & - & - & - & - \\
\hline North Central & 0.00 & 0.02 & 3.74 & 7.74 & 0.44 & 0.34 & - & - & 220.5 & 32.17 \\
\hline West & 1.16 & 1.06 & 0.54 & 0.38 & 1.03 & 1.01 & - & - & - & - \\
\hline Southeast & 1.21 & 1.07 & - & - & 1.02 & 0.98 & - & 0.02 & - & - \\
\hline Southwest & 1.20 & 0.92 & - & - & 1.02 & 0.87 & - & 2.37 & - & 0.12 \\
\hline
\end{tabular}

Source: Authors, 2016

Fonte: Autores,2016. 


\section{DISCUSSION}

\section{Yerba Mate}

Tables 1 and 2 show that yerba mate is a native NTFP whose production is decentralized. Out of the ten mesoregions that make up Paraná, eight regions register production and have few LQs above 1. This is checked in six mesoregions and ranges from 0.11 (2010) to 1.03 (2014), meaning that in addition to the dispersion in production, some regions have a higher production at the expense of others. However, the LQ does not show the weight of each municipality. Nevertheless, the database shows that the Southeastern region has greater representation considering the five municipalities with the highest production and value-Cruz Machado, São Mateus do Sul, Bituruna, Paula Freitas, and General Carneiro-accounting for 51.86\% and 57.8\% of the total production and total value of production in 2010 and in 2014. There is little dispersed production in the municipalities for the metropolitan region of Curitiba, while there is the tendency for the extinction of yerba mate cultivation in the North Central mesoregion, whose LQ is close to zero.

The region beyond regarding the LQ for the value of yerba mate production, it appears that there is little difference in the LQ's value of production compared to the amount produced, as verified in the analyzed database. This occurs for various production regions, but the metropolitan region of Curitiba had its LQ (2010-production) reduced from 0.43 (Table 1) to 0.11 (2010 value of production) (Table 2) and 0.43 LQ (2014-production) (Table 1) reduced to 0.20 (2014-production value) (Table 2), indicating that the low productivity is the little value. It is worth clarifying that even regions that have low productivity can earn better prices, that is, the value of production is greater in relation to the smaller amount produced when compared to other regions. The higher value is justified by the higher marketing price. Another case is the north-central middle region, which has the lowest values for both the amount produced and the value of production. In addition to low productivity, value traded is less representative if the NTFP is purchased from other regions.

\section{Palm Heart}

Palm heart grows in six out of the ten mesoregions of Paraná. Overall, 51 municipalities produce palm heart, but only four municipalities contribute to the concentration of production: Guaraqueçaba, Morretes, Guaratuba, and Antonina (all of the Curitiba metropolitan mesoregion). In 2010, palm heart accounted for 57.53\% of the total production and $56.35 \%$ of the total production value. The difference in percentage is a result of the difference in the marketing values for the same product since a higher production is not always synonymous with a higher value. Five municipalities account for $80.62 \%$ of the production and $80.62 \%$ of the total value in 2014: Guaraqueçaba, Antonina, Guaratuba, Morretes, which are located in the Curitiba metropolitan mesoregion, and Sao Tome, which is located in the Northwest middle region. The LQs calculated show that the production of palm heart is highly concentrated. A total of $60 \%$ of those mesoregions produce palm hearts, and in quantity and value only five municipalities have greater representation.

For the palm hearts analyzed in six producing mesoregions, the calculated LQs for the gross value of production in five of these decreased. This shows that although there is some amount of production, there is great decentralization in production, and the amounts traded are low among municipalities. However, the West mesoregion showed a slight increase in LQs considering production, which is 0.47 (2010) and 0.37 (2014) in Table 1 and the production value, which is 0.54 (2010) and 0.38 (2014) in Table 2, showing that although the region has little commercial representation, the value of marketed palm heart appreciated slightly.

\section{Pinhão}

Pinhão is a unique NTFP that appears in all of the mesoregions, and like yerba mate, few mesoregions have LQs above 1, indicating a dispersion in production, with a few contributing in large quantities to the production of the state. The variation of LQ between 2010 and 2014 indicates that, overall, there was a shift in the trend of production since the Center-West had LQ increase from 1.00 to 1.27 (Table 1), indicating a significant location of production. The Curitiba metropolitan mesoregion also showed an increase in pinhão production concentration, from an LQ of 0.91 (several producing municipalities) in Table 1 to an LQ of 1.95 in Table 1 (few producer municipalities). About 38\% of the production in 2014 was concentrated in five municipalities: Pinhão, Guarapuava, Turvo, Inácio Martins (all in South-Central mesoregion), and Imbituva (Southeast mesoregion). The data indicate that the South-Central mesoregion produced more pinhão in the state that year, accounting for 33\% of the total production. The mesoregion with greater production is precisely in the area of the natural occurrence of Araucaria Forest, conducive to the development of the Araucaria tree.

For pinhão, despite the low concentration of production revealed by the LQ, in terms of value, there was a shift in the production value between the producer mesoregions. Between 2010 and 2014, the Northwest mesoregion, the Central Eastern mesoregion, and the Curitiba metropolitan mesoregion had a small increase in the 
value of production. The highlight is the South-Central mesoregion, which had a significant increase in its production value during this period, leaving LQ 0.96 (average location) for LQ 3.7 (significant location), even though the LQ in relation to the quantity produced does not change accordingly. The SEAB (2016) points out that the average price of pine nuts in the state rose from $\mathrm{R} \$ 1.25$ in 2012 to $\mathrm{R} \$ 3.26$ in 2014, i.e., it follows that the price of this product rose above average in this middle region than it did in others. The North Pioneer mesoregion, the North Central mesoregion, the West mesoregion, the Southeast mesoregion, and the Southwest mesoregion lost production value in the period, confirming the hypothesis of a change in the production value of the mesoregion.

\section{Resin}

Resin was produced in only three mesoregions in 2010: The Central-Eastern mesoregion, the Central Southern mesoregion, and the Curitiba metropolitan mesoregion. In 2014, was remarked that the East and Central mesoregion (high concentration of production in 2010) did not produce resin; however, the East mesoregion and the West mesoregion appear as producing resin, indicating a shift of production in the state. Cerro Azul, Francisco Beltrao, Guarapuava, Laranjeiras do Sul, and Dr. Ulysses became the main resin producers in the state, accounting for $79 \%$ of the production area.

There was a major change in the production of resin between 2010 and 2014, a result of the change in the producing regions in the period. In 2010, all the production was concentrated in three mesoregions. In 2014, the East Central region does not provide information on production in 2014, even with the high concentration of production value in 2010. Due to the evolution of production in Southeast (poor location) and Southwest (significant location), the South-Central mesoregion and the Curitiba metropolitan mesoregion lost production value in the period.

\section{Latex}

Production was observed in two mesoregions in 2010: Northwest and North Central. The expressive values of the LQ indicate that production is highly concentrated in a few towns in the middle region. In 2014, it appears the latex production increased in Southwest mesoregion, in the municipality of Pranchita but with an LQ indicating poor location, that is, low resin production in relation to the total production of the mesoregion. The change in LQ between 2010 and 2014 indicates an increase in the concentration of production, and in 2014, only five municipalities accounted for $83.43 \%$ of the latex production in the state: Paranapanema, Paranavaí, Paraná, President Castelo Branco, and Paranacity.

The production value for latex increased in 2014 in both of the mesoregions that were producing latex in 2010. However, the Southwest mesoregion shows a low production value in 2014, indicating new crops.

\section{Regional concentration}

The map below shows the concentration of the analyzed crops:

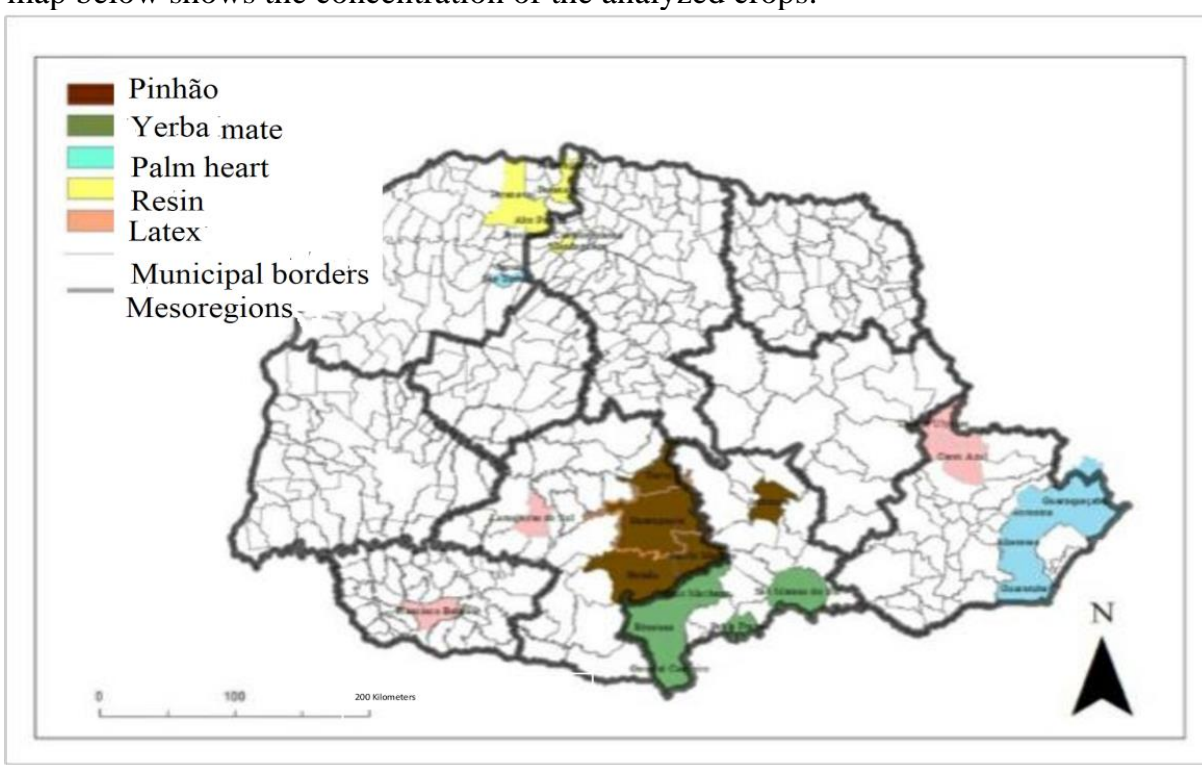

Source: Authors

Fonte: Autores 
Figure 2 - Regions of 5 municipalities of greater production of each NTFP.

Figura 2 - Região de 5 municípios de maior produção de cada PFNM.

The map (Figure 2) highlights the regions with the highest concentration of productive and/or increased value of production (value). For yerba mate, the following regions stand out: Cruz Machado, São Mateus do Sul, Bituruna, and Paula Freitas. For palm heart, Guaraqueçaba, Morretes, Guaratuba, Antonina, and São Tome stand out. For pinhão the following regions stand out: Cerro Azul, Francisco Beltrao, Guarapuava, South Orange and Dr. Ulysses. For resin, Cerro Azul, Francisco Beltrao, Guarapuava, Laranjeiras do Sul, and Dr. Ulysses stand out. For latex, Paranapanema, Paranavaí, Presidente Castelo Branco, and Paranacity stand out. Their crops have concentrations in a few cities, so it is understood that this production can be derived or can complement the income in relation to the other participants.

\section{CONCLUSIONS}

- The production of yerba mate is decentralized regarding the number of municipalities participating in its production. However, when this is analyzed by mesoregion, there is concentration of production of just over $50 \%$ in the Southeast mesoregion. In this scenario, technical assistance is crucial that producers can use the cultivation of yerba mate as a form of income supplement.

- Many municipalities (51) produce palm heart. However, over 80\% (2014) of the production is concentrated in the Curitiba metropolitan mesoregion. The regulation of the cultivation of palm heart by the environmental authority of the state, even of species not protected by law, results in uncertainty for producers, even generating an illegal market and, consequently, unfair competition, often causing impracticability of production.

- Pinhão is produced in 124 municipalities, distributed in all the mesoregions. However, the analysis of LQ showed a high concentration of some of these. Five of these municipalities, Pinhão, Guarapuava, Turvo, Inácio Martins, and Imbituva, account for $38.4 \%$ of all the production value. This is an important product for the community of Paraná that has its production (collection and sale) regulated by the state, but with the exception of trade regulation, which lacks a policy for its development.

- Resin has a highly concentrated production, with only five municipalities accounting for $79 \%$ of the production value. This occurs due to the concentration of Pinus elliotti in these regions and their production is dependent on new crops and/ or increasing demand in the resin industry.Similar to resin, latex has a high concentration of production and output value, since rubber is grown in the hottest regions of the state only. Paranapanema municipality produced $830,150,000$ tons in 2014 , which generated a production value of $\mathrm{R} \$$ $2,050,470$ equivalent to $61.7 \%$ of the total production of the state in a single municipality.

- Considering the objectives of this study, it was verified that the regional analysis using LQ, both for production and for production value, has proved to be a valuable tool to characterize the mesoregions of Paraná in their participation in the production of the five most important NTFPs in the State of Paraná, in addition to identifying the productive potential of the five most important NTFPs. In other words, was demonstrated in which regions there is a concentration or not of the production of the products studied, as well as the regions in which there is greater representativeness by the added value. The productive potential is also verified by the LQ indicating the level of concentration by the area studied. Regarding current and future actions aimed at the development of the regions, it is possible for the government to use LQ as part of its public policy planning to allow society to benefit from the development of NTFPs. The new Forestry Law, which is in the process of being drafted, must contain the new vision for NTFPs in the state, allowing the development of programs and projects whose results can exploit the productive potential of NTFPs in the State of Paraná.

\section{REFERENCES}

CLEMENTE, A. Economia Regional: introdução a economia do espaço geográfico. 2.ed. Curitiba: UFPR 1992.

CLEMENTE, A.; HIGACHI, Y. H. Economia e Desenvolvimento Regional. São Paulo: Atlas 2000.

FAO. Non-wood forest products for rural income and sustainable forestry. Disponível em:<http://www.fao.org/docrep/V9480E/v9480e04.htm\#why\%20are\%20non\%20wood\%20forest\%20products\% 20important>. Acesso em: 24 Mai. 2016. 
Instituto Brasileiro de Geografia e Estatística (IBGE) - Produção da extração vegetal e silvicultura 2014. Disponível em: < http://www.ibge.gov.br/home/estatistica/economia/pevs/2014/>. Acesso: em 10 Mai. 2016.

LIMA, J. F. de; ALVES, L. R.; PIFFER, M.; PIACENTI,C. A.; Análise regional das mesorregiões do estado do Paraná no final do século XX .Análise Econômica. [Porto Alegre], v. 24, n.46; set.., 2006. Disponível em:< <http://seer.ufrgs.br/AnaliseEconomica/article/view/10845/6438>. Acesso em: 25 Jun. 2016.

MARION FILHO, P. J.; MOURA, A. C.; BRITES, M.; LORENZONI, R. K.C oncentração regional e especialização na produção de leite do Rio Grande do Sul (1990 - 2010). Revista Brasileira de Gestão e Desenvolvimento Regional, Taubaté , v. 11, n. 1, p. 224-242, jan-abr/2015.

SANTOS, A. J.; HILDEBRAND, E.; PACHECO, C. H. P.;TARSO, P. L.; ROCHADELLI, R. Produtos não madeireiros: conceituação, classificação, valoração e mercados. Disponível em:<http://ojs.c3sl.ufpr.br/ojs/index.php/floresta/article/view/2275 >. Acesso em: 10 Mai. 2016.

SEAB. Produtos $\quad$ Florestais. Disponível em:< http://www.agricultura.pr.gov.br/arquivos/File/deral/Prognosticos/produtos_florestais_2014_2015.pdf >. Acesso em: 25 Jun. 2016.

SEAB. Valor Bruto da Produção Agrícola Paranaense em 2017. Disponível em: <http://www.agricultura.pr.gov.br/arquivos/File/deral/AnaliseVBP2017ResumidaVD.pdf>. Acesso em: 17 set. 2018. 